\title{
Rancang Bangun Aplikasi Seleksi Abstrak dan Full Paper pada Seminar Nasional
}

\author{
Designing Abstract Selection and Full Paper Application on the National Seminar web
}

\author{
Aneke Rintiasti \\ Baristand Industri Surabaya \\ Kementerian Perindustrian \\ Surabaya, Indonesia \\ anekerintiasti@gmail.com
}

\author{
Adhe Rama Febrianto \\ Jurusan Manajemen Informatika \\ Sekolah Tinggi Ilmu Komputer (STIKOM) \\ Surabaya, Indonesia \\ adheramaf7@gmail.com
}

\begin{abstract}
Abstrak - proses seleksi dan pencatatan hasil seleksi abstrak dan paper dilakukan secara manual, sehingga mengakibatkan sering tidak tepatnya pencatatan serta pelaporan hasil seleksi yang dilakukan oleh panitia. Untuk menyelesaikan permasalahan yang terjadi pada proses secara manual tersebut, perlu adanya aplikasi seleksi abstrak dan paper seminar nasional. Dengan diterapkannya aplikasi ini, diharapkan dapat mengurangi risiko kesalahan pencatatan dan pelaporan hasil seleksi abstrak dan paper yang dikirim oleh calon pemakalah. Aplikasi ini juga diharapkan dapat lebih mempercepat proses pembuatan laporan yang pada akhirnya dapat membantu kinerja panitia seminar nasional. Hasil penelitian menunjukkan bahwa penelitian ini mengolah dan menampilkan data paper yang diunggah calon pemakalah, mengolah dan menampilkan data paper yang diunggah calon pemakalah, menghasilkan laporan daftar abstrak dan paper yang diunggah calon pemakalah, menghasilkan laporan daftar abstrak dan paper yang dinyatakan diterima, menghasilkan laporan daftar abstrak dan paper yang dinyatakan tidak diterima.
\end{abstract}

Kata kunci-sistem informasi, seminar nasional, seleksi, abstrak

Abstract - Process Selection and recording process of abstract and paper selection results is done manually, resulting in frequent incorrect recording and reporting of selection results conducted by the committee. To solve the problems that occur in the process manually, the need for an application of abstract selection and paper at a national seminar. With the implementation of this application, it is expected to reduce the risk of recording and reporting of abstract and paper selection results sent by potential candidates. This application is also expected to further accelerate the process of making reports that can ultimately help the performance of the national seminar committee. The result of this research shows that this research is processing and displaying paper data uploaded by the candidate speakers, processing and displaying paper data uploaded by candidate speaker, producing report of abstract list and paper uploaded by candidate speaker, producing report of abstract list and paper which is accepted, producing report report abstracts and papers declared not accepted.

Keywords - information systems, national seminars, selection, abstract

\section{PENDAHULUAN}

Seminar Nasional adalah seminar yang dilaksanakan secara nasional (antar wilayah dalam satu Negara) dan dilakukan secara terencana dengan topik tertentu yang spesifik yang diagendakan secara nasional melibatkan narasumber nasional atau narasumber luar negeri yang bereputasi melibatkan peserta nasional atau peserta luar negeri yang tidak terencana informasi dan pemberitahuan (brosur) secara nasional dalam media jurnal nasional dalam waktu 1 (satu) tahun dengan agenda yang terstruktur dan pasti [9].

Pada kegiatan seleksi abstrak dan paper seminar nasional, panitia melakukan seleksi secara manual dan hasil seleksi dicatat dalam bentuk catatan kemudian dipindah ke aplikasi Microsoft Excel. Agar lebih menunjang kegiatan seleksi abstrak dan paper seminar nasional yang diadakan, diperlukan aplikasi yang terintegrasi dengan database. Keunggulan yang didapat jika dibandingkan dengan sistem pencatatan tertulis maupun dengan Microsoft Excel adalah, kecilnya kemungkinan human error, serta lebih mudahnya melakukan pembuatan laporan hasil seleksi.

Aplikasi Seleksi Abstrak dan Paper ini merupakan aplikasi yang menangani pengolahan data abstrak dan paper yang diunggah oleh calon pemakalah, serta laporan yang berkaitan dengan hasil seleksi abstrak dan paper. Agar dapat mengolah data-data dengan baik maka dibutuhkan aplikasi yang dapat menampilkan data-data abstrak dan paper yang diunggah oleh calon pemakalah dan fungsi untuk melakukan seleksi pada abstrak dan paper. Di dalam aplikasi ini terdapat beberapa fungsi cetak laporan seperti: laporan abstrak dan paper yang sudah diunggah peserta, laporan abstrak dan paper yang diterima, dan laporan abstrak dan paper yang tidak diterima. Diharapkan dengan adanya fungsi tersebut dapat menangani permasalahan yang ada dalam rancang bangun aplikasi seleksi abstrak dan paper seminar nasional yang ada pada Baristand Industri Surabaya.

Secara garis besar permasalahan yang diidentifikasi pada sistem ini yaitu sering kali terjadinya kesalahan pencatatan hasil seleksi dan laporan yang tidak sesuai. Data-data seleksi yang ada juga menumpuk terlalu banyak sehingga proses pencarian data seleksi terkesan lama. Laporan yang kurang detail seperti tidak adanya laporan seperti laporan abstrak dan paper yang diterima, dan laporan abstrak dan paper yang tidak diterima. Terdapatnya kesalahan dalam proses seleksi sehingga 
membuat laporan yang dihasilkan tidak sesuai. Dengan adanya teknologi informasi yang berkembang saat ini sangat memungkinkan untuk menggunakan sistem yang terkomputerisasi demi meningkatkan ketepatan dalam proses seleksi abstrak dan paper seminar nasional di Baristand Industri Surabaya.

Penelitian sebelumnya [1] mengembangkan Sistem Informasi Pendataan Petani dan Kelompok Tani menggunakan metode SDLC [2] mengembangkan Sistem Informasi Manajemen Pencatatan Aset Berbasis Web dengan metode UML [3] mengembangkan sistem informasi penerimaan siswa baru berbasis web dengan PHP dan SQL. Sedangkan web yang menangani seminar yang ada saat ini easychair [10] atau edas [11] masih ditemukan kesulitan setelah abstrak / paper direview, karena hanya dikirimi notifikasi ke email masingmasing tidak bisa terlihat di menu upload pemakalah.

Tabel 1. Gap Analysis dengan Aplikasi Seminar yang ada

\begin{tabular}{|c|c|c|c|c|}
\hline \multirow{2}{*}{ No } & \multirow{2}{*}{ Feature } & \multicolumn{3}{|c|}{ Aplikasi } \\
\hline & & Semnas & Edas & EasyChair \\
\hline 1 & Login & $\begin{array}{l}\text { Berdasar } \\
\text { Email dan } \\
\text { password }\end{array}$ & $\begin{array}{l}\text { Berdasar } \\
\text { Email dan } \\
\text { password }\end{array}$ & $\begin{array}{l}\text { Berdasar } \\
\text { username } \\
\text { dan } \\
\text { password }\end{array}$ \\
\hline 2 & $\begin{array}{c}\text { Forget } \\
\text { Password }\end{array}$ & $\begin{array}{c}\text { Link reset } \\
\text { password } \\
\text { dikirim via } \\
\text { email }\end{array}$ & $\begin{array}{c}\text { Link reset } \\
\text { password } \\
\text { dikirim via } \\
\text { email }\end{array}$ & $\begin{array}{c}\text { Link reset } \\
\text { password } \\
\text { dikirim via } \\
\text { email }\end{array}$ \\
\hline 3 & $\begin{array}{l}\text { Paper / } \\
\text { Article } \\
\text { Submit }\end{array}$ & $\begin{array}{c}\text { Diupload } \\
\text { via form } \\
\text { setelah } \\
\text { login }\end{array}$ & $\begin{array}{l}\text { Diupload } \\
\text { via form } \\
\text { setelah } \\
\text { login }\end{array}$ & $\begin{array}{l}\text { Diupload } \\
\text { via form } \\
\text { setelah } \\
\text { login }\end{array}$ \\
\hline 4 & $\begin{array}{l}\text { Paper / } \\
\text { Article } \\
\text { Review }\end{array}$ & $\begin{array}{c}\text { Hanya bisa } \\
\text { dilakukan } \\
\text { oleh admin } \\
\text { internal }\end{array}$ & $\begin{array}{c}\text { Bisa } \\
\text { dilakukan } \\
\text { oleh admin } \\
\text { internal } \\
\text { dan } \\
\text { reviewer } \\
\text { luar }\end{array}$ & $\begin{array}{c}\text { Bisa } \\
\text { dilakukan } \\
\text { oleh admin } \\
\text { internal } \\
\text { dan } \\
\text { reviewer } \\
\text { luar } \\
\end{array}$ \\
\hline 5 & $\begin{array}{c}\text { Hasil } \\
\text { Review } \\
\text { Paper / } \\
\text { Article }\end{array}$ & $\begin{array}{l}\text { Bisa dilihat } \\
\text { di menu } \\
\text { upload } \\
\text { paper/ } \\
\text { artikel dan } \\
\text { juga } \\
\text { dikirimi } \\
\text { email } \\
\text { notifikasi } \\
\text { ke email } \\
\text { masing- } \\
\text { masing. }\end{array}$ & $\begin{array}{c}\text { Dikirimi } \\
\text { notifikasi } \\
\text { ke email } \\
\text { masing- } \\
\text { masing }\end{array}$ & $\begin{array}{c}\text { Dikirimi } \\
\text { notifikasi } \\
\text { ke email } \\
\text { masing- } \\
\text { masing }\end{array}$ \\
\hline
\end{tabular}

Tujuan penelitian ini yaitu :

a. Mengolah dan menampilkan data abstrak yang diunggah calon pemakalah.

b. Mengolah dan menampilkan data paper yang diunggah calon pemakalah. c. Mengolah dan menampilkan data review abstrak yang diunggah oleh redaksi

d. Menghasilkan laporan daftar abstrak dan paper yang diunggah calon pemakalah.

e. Menghasilkan laporan daftar abstrak dan paper yang dinyatakan diterima.

f. Mengolah dan menampilkan data review paper yang diunggah oleh redaksi

g. Menghasilkan laporan daftar abstrak dan paper yang dinyatakan tidak diterima.

\section{BAHAN DAN METODE}

Bahan yang digunakan untuk mengembangkan aplikasi sesuai dengan spesifikasi kebutuhan dibutuhkan lingkungan operasi sebagai berikut :

- Sistem Operasi Windows

Sistem operasi ini dipilih karena dibutuhkan suatu component Windows 7, Windows 8 atau Windows 10.

- XAMPP v3.2.2

XAMPP digunakan sebagai webserver untuk menjalankan aplikasi berbasis web.

- MySQL

MySQL digunakan karena terintegrasi dengan XAMPP.

Berikut ini adalah hardware dan software yang dibutuhkan untuk implementasi Aplikasi Seleksi Abstrak dan Paper Seminar Nasional yaitu :

\section{Software Pendukung}

- Sistem Operasi Microsoft Windows 7 Ultimate Version 2009.

- $\quad$ Xampp V.5.6.19

\section{Hardware Pendukung}

- Komputer dengan processor Core i3 M 370 @ 2.40 $\mathrm{GHz}$ atau lebih tinggi.

- Graphic Intel 32-bit dengan resolusi 1366 x 768 atau lebih tinggi. Memori RAM 2.00 GB atau lebih tinggi. Aplikasi ini dikembangkan menggunakan metode System Development Life Cycle (SDLC). Terdapat 4 tahap proses pengembangan sistem yaitu perencanaan, analisis, perancangan, dan implementasi sistem.

\section{HASIL DAN PEMBAHASAN}

Document flow memuat hasil analisis yang dibuat berdasarkan hasil wawancara pada Baristand Industri Surabaya. Document flow menggambarkan seluruh proses yang berhubungan dalam kegiatan seleksi abstrak dan paper secara manual sebelum adanya aplikasi seleksi abstrak dan paper yang akan dirancang sekarang ini.

a) Document Flow Seleksi Abstrak Calon Pemakalah Pada Gambar 1 menjelaskan proses awal dimulai pada calon pemakalah yang mengirim abstrak yang diseleksi oleh panitia seminar nasional. Hasil seleksi dicatat oleh panitia. Setelah itu hasil seleksi diumumkan sesuai dengan jadwal yang sudah ditentukan panitia. 


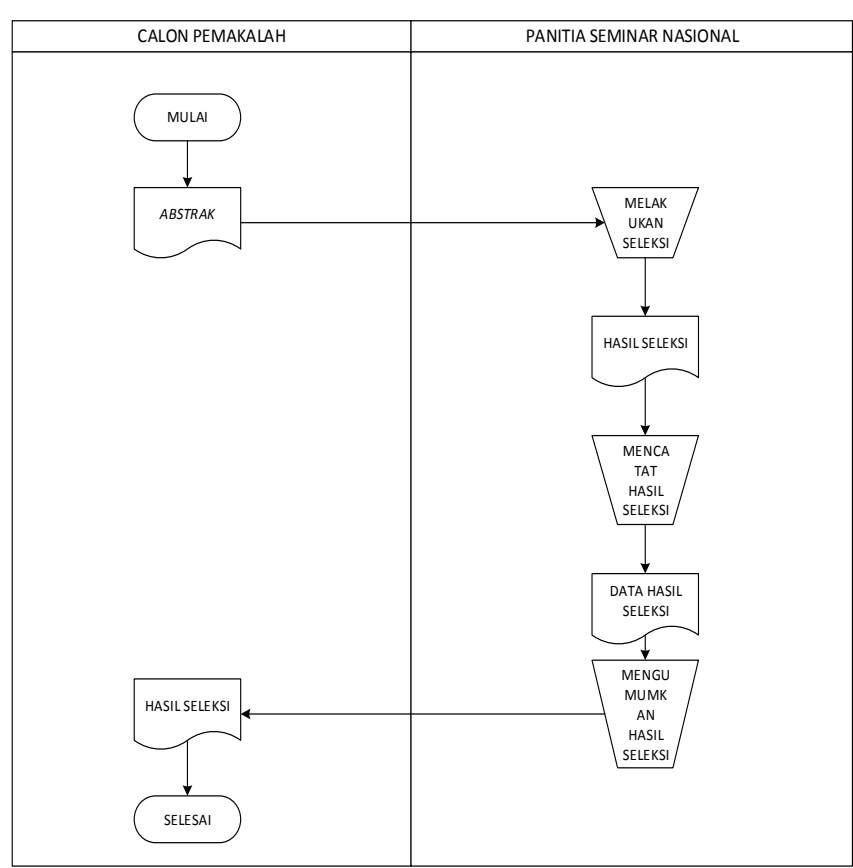

Gambar 1. Document Flow Seleksi Abstrak Calon Pemakalah

b) Document Flow Seleksi Paper Calon Pemakalah

Pada Gambar 2 menjelaskan proses awal dimulai pada calon pemakalah yang mengirim paper yang diseleksi oleh panitia seminar nasional. Hasil seleksi dicatat oleh panitia. Setelah itu hasil seleksi langsung diberitahukan kepada calon pemakalah.

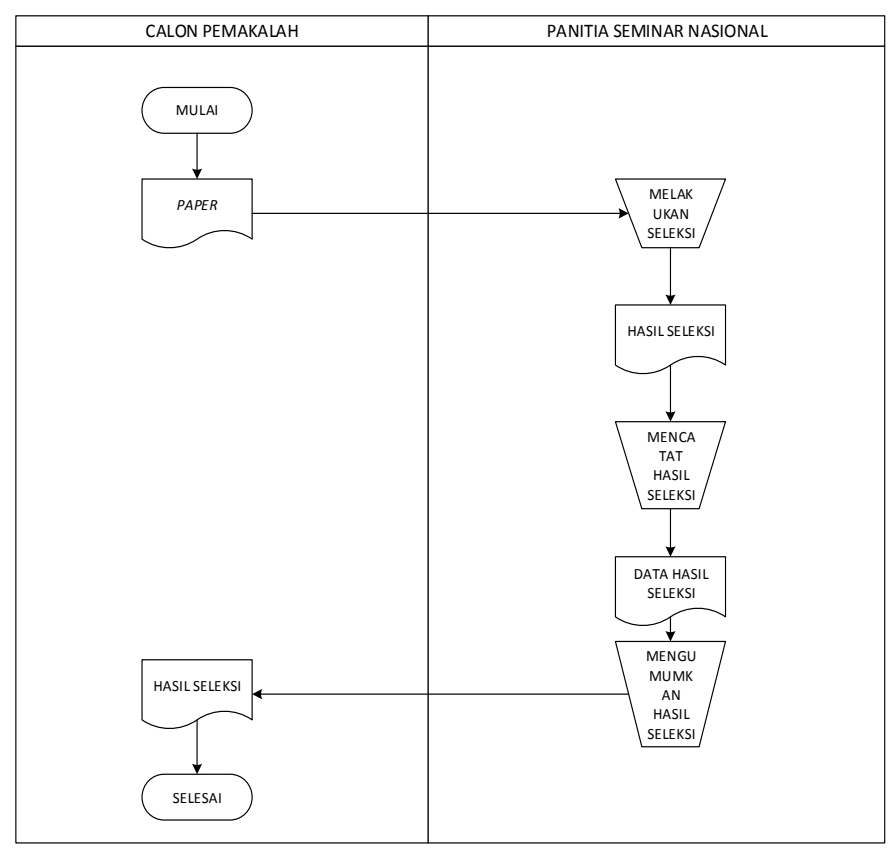

Gambar 2. Document Flow Seleksi Paper Calon Pemakalah

Berdasarkan Document Flow diatas desain sistem pada aplikasi ini meliputi System Flow dan Data Flow Diagram.

a) System Flow Upload Abstrak
Pada Gambar 3 menjelaskan proses pengiriman atau upload data abstrak yang dilakukan oleh calon pemakalah secara terkomputerisasi. Setelah itu masuk ke proses seleksi abstrak oleh panitia atau admin secara terkomputerisasi.

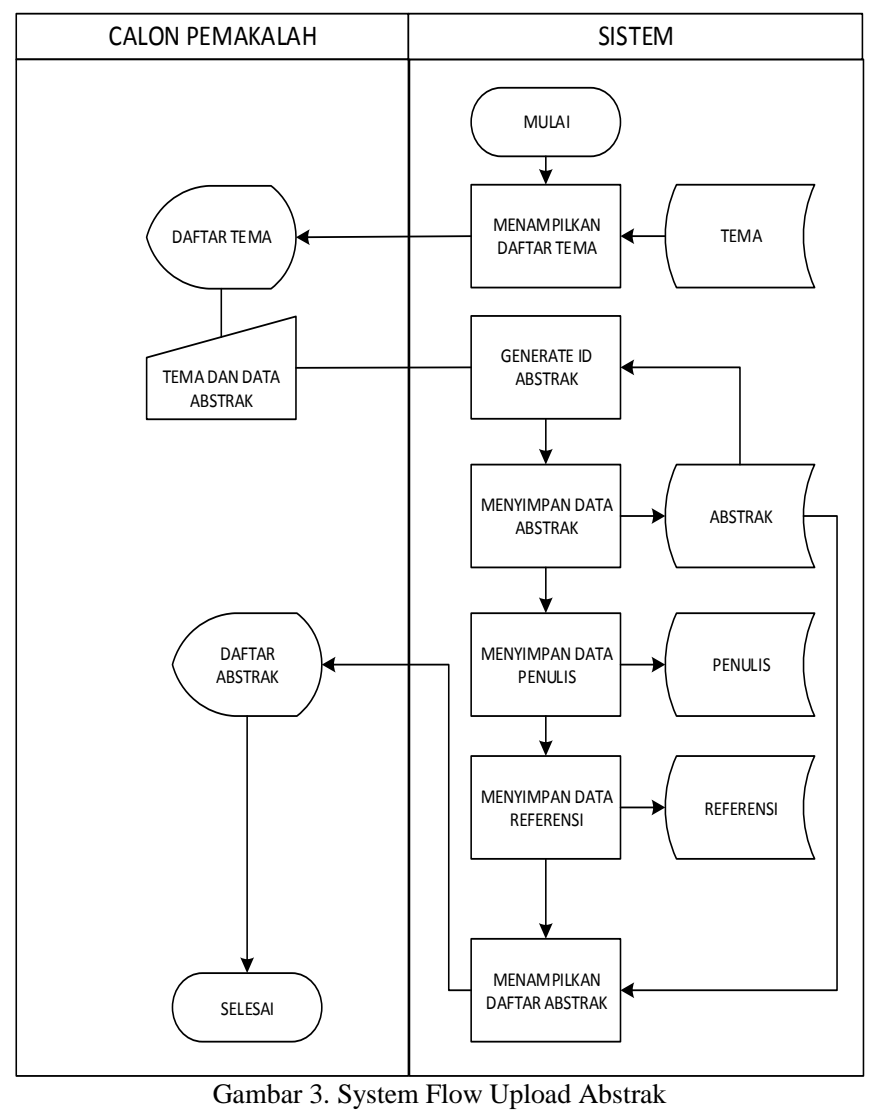

b) System Flow Seleksi Abstrak

Pada Gambar 4 menjelaskan proses seleksi secara terkomputerisasi pada sisi admin atau panitia. Panitia memilih abstrak yang akan dilakukan review kemudian menginputkan hasil review secara terkomputerisasi. 


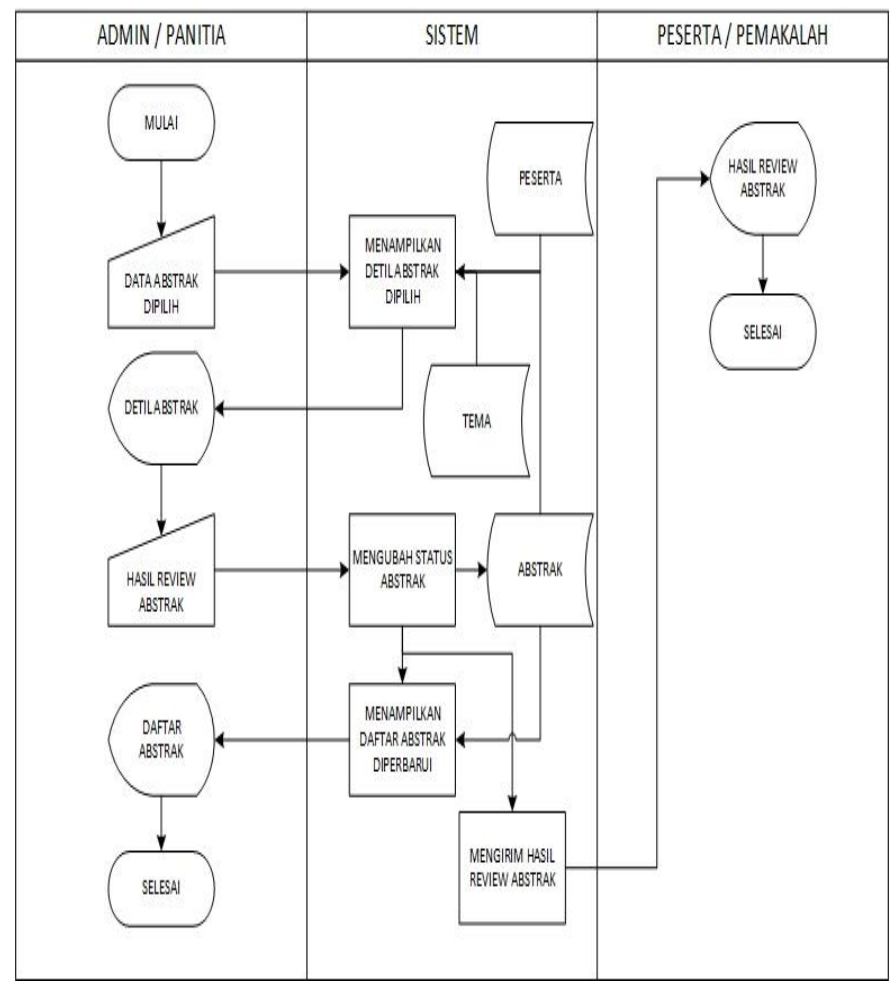

Gambar 4. System Flow Seleksi Abstrak

c) System Flow Upload Paper

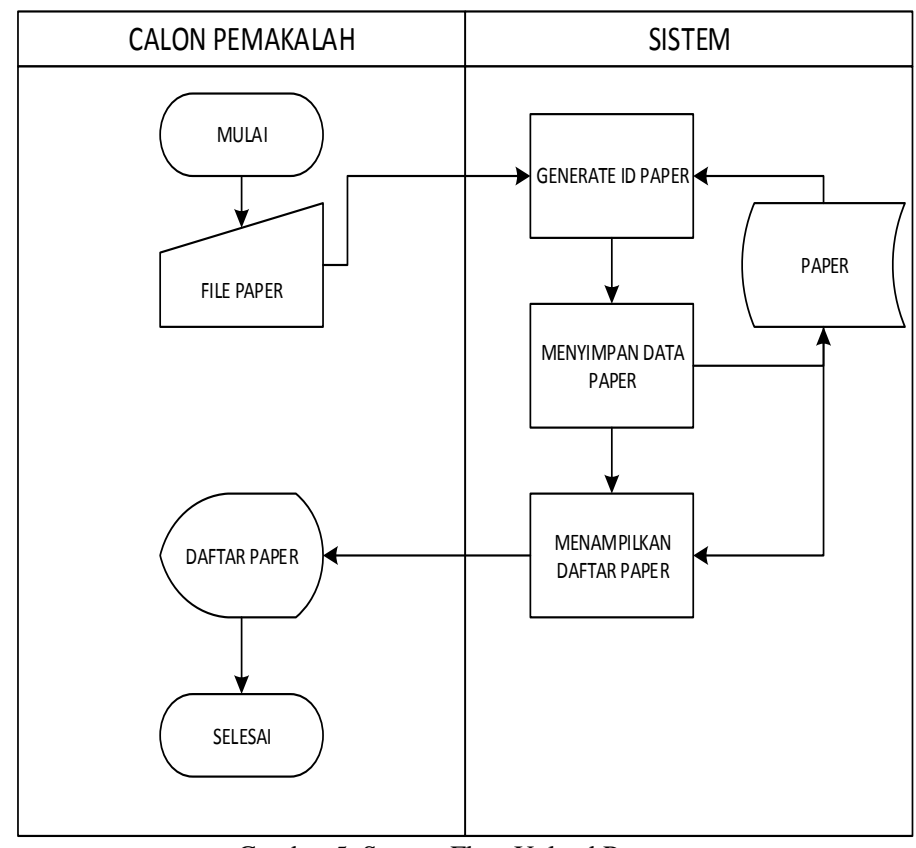

Gambar 5. System Flow Upload Paper

Pada Gambar 5 menjelaskan proses pengiriman atau upload file paper yang dilakukan oleh calon pemakalah secara terkomputerisasi. Setelah itu masuk ke proses seleksi paper oleh panitia atau admin secara terkomputerisasi.

\section{d) System Flow Seleksi Paper}

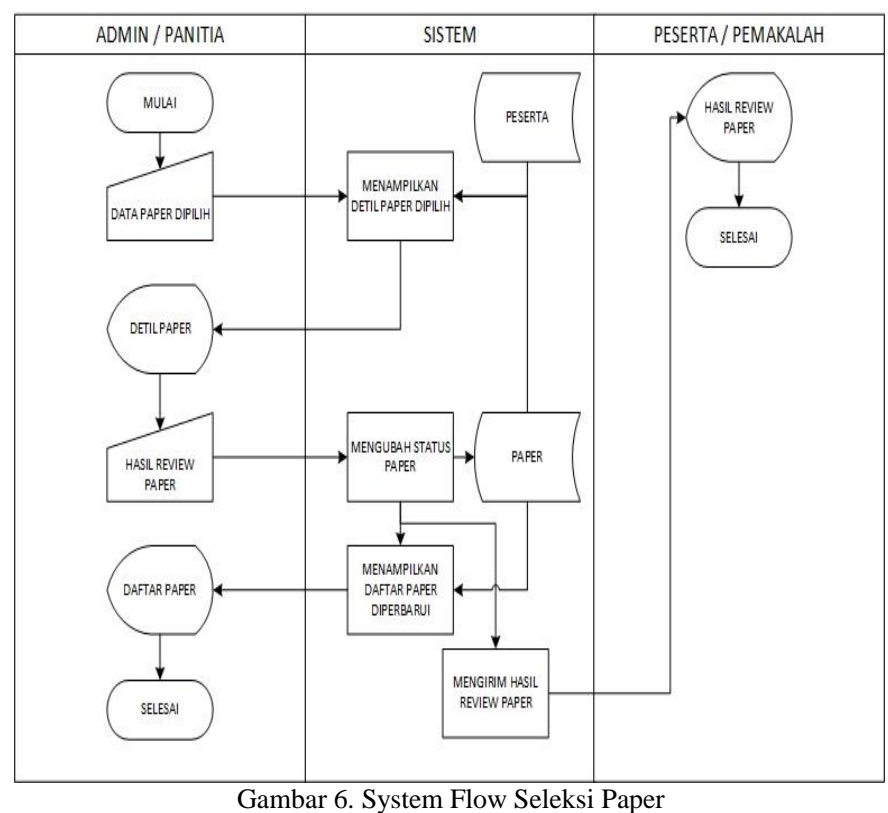

Pada Gambar 6 menjelaskan proses seleksi paper secara terkomputerisasi pada sisi admin atau panitia. Panitia memilih paper yang akan dilakukan review kemudian menginputkan hasil review secara terkomputerisasi.

\section{Context Diagram}

Pada Gambar 4.8 adalah context diagram dari Rancang Bangun Aplikasi Seleksi Abstrak dan Paper Seminar Nasional. Context diagram sistem ini terdiri dari 2 (dua) entitas, yaitu entitas admin dan entitas calon pemakalah. Dua entitas tersebut memberikan input data dan menerima output data yang diperlukan.

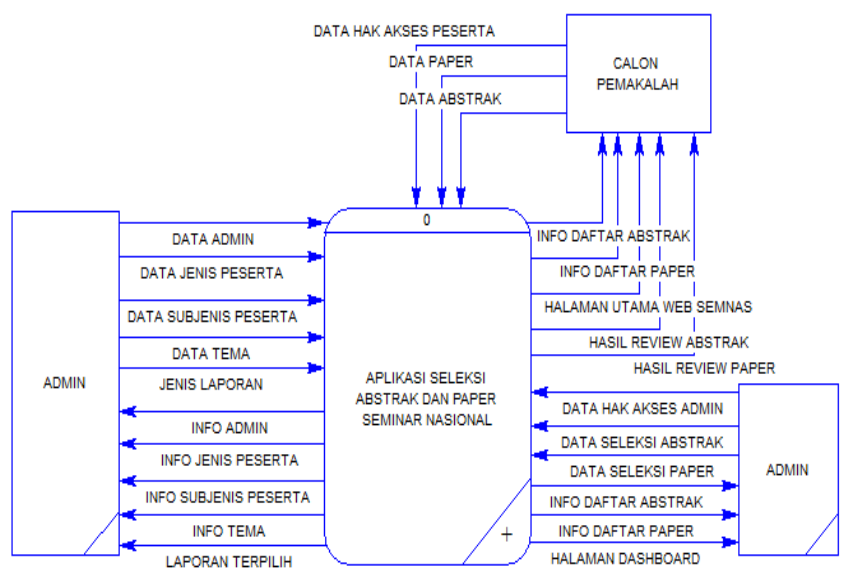

Gambar 7 Context Diagram 


\section{Physical Data Model (PDM)}

Pada Gambar 8 merupakan Physical Data Model (PDM) yang telah di-generate dari CDM pada Rancang Bangun Aplikasi Seleksi Abstrak dan Paper Seminar Nasional studi kasus Baristand Industri Surabaya. PDM terdiri dari sebelas tabel yang saling berhubungan, tabel-tabel tersebut antara lain tabel jenis peserta, tabel subjenis peserta, tabel tema, tabel admin, tabel provinsi, tabel kabupaten, tabel peserta, tabel abstrak, tabel penulis, tabel referensi, serta tabel paper

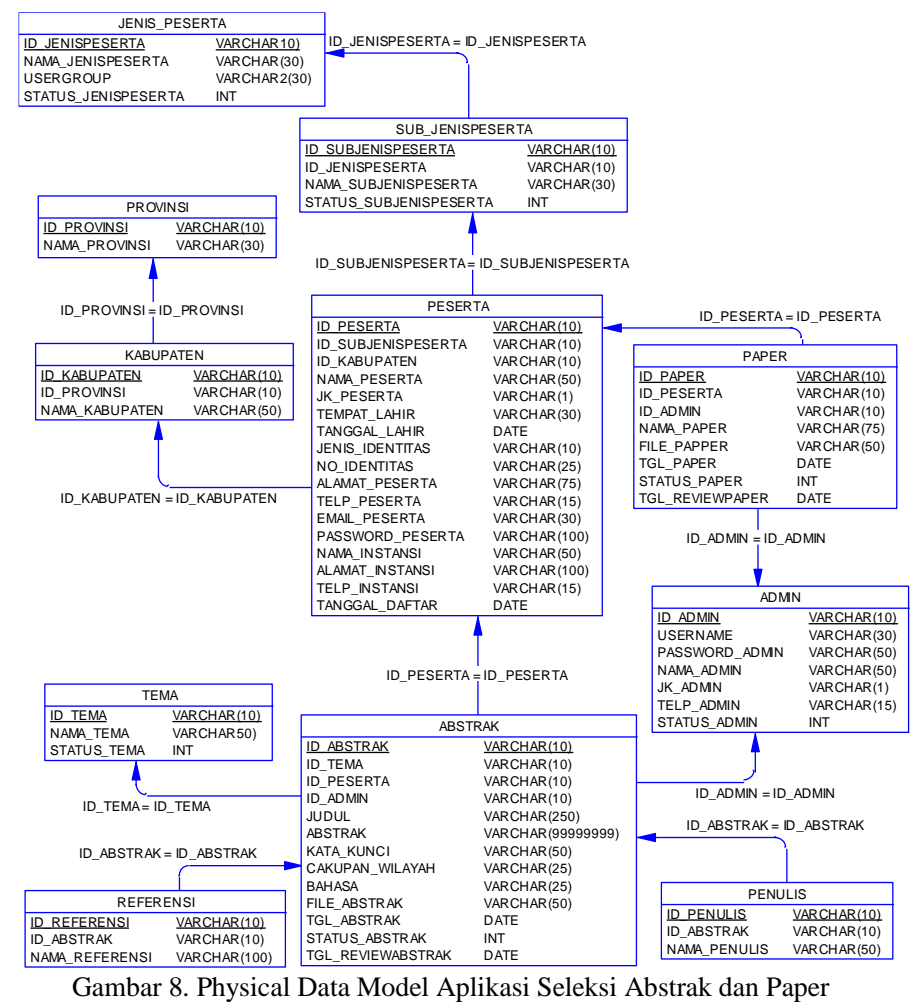

\section{Antar Muka Aplikasi}

\section{a) Halaman Login}

Aplikasi seleksi abstrak dan paper mengharuskan pengguna melakukan login untuk dapat mengakses fitur dari aplikasi. Karena fitur-fitur pada aplikasi ini dapat diakses apabila username dan password yang dimasukkan sesuai dengan username dan password yang ada pada database.

Untuk halaman login admin, username dan password diisi sesuai dengan yang dimiliki masing-masing admin. Lebih jelasnya dapat dilihat pada Gambar 9.

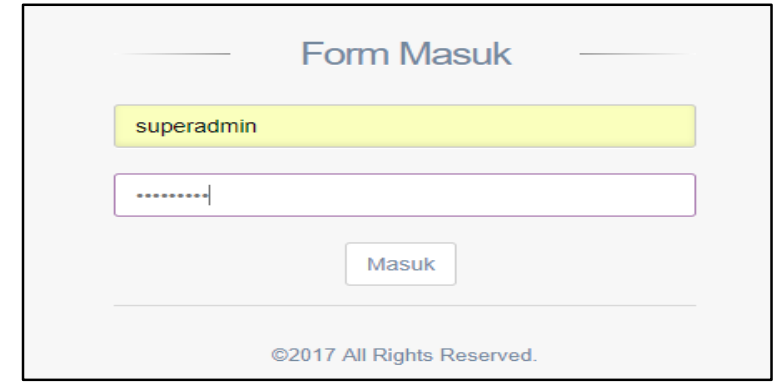

Gambar 9 Halaman Login Admin

Apabila username dan atau password yang dimasukkan tidak sesuai dengan yang ada di database maka sistem akan memuat ulang halaman dan menampilkan notifikasi berwarna merah di pojok kanan bawah halaman bertuliskan "Username dan atau Password Salah". Lebih jelasnya dapat dilihat pada Gambar 10.

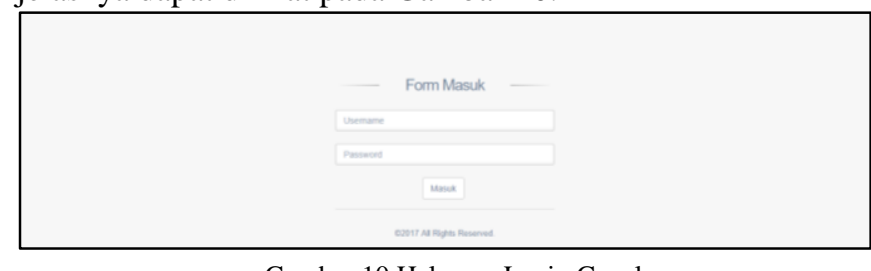

Gambar 10 Halaman Login Gagal

Ketika pengguna berhasil memasukkan username dan password yang sesuai, sistem akan mengarahkan pengguna ke Halaman Dashboard Admin dan muncul notifikasi berwarna hijau bertuliskan "Selamat Datang". Lebih jelasnya dapat dilihat pada Gambar 11.

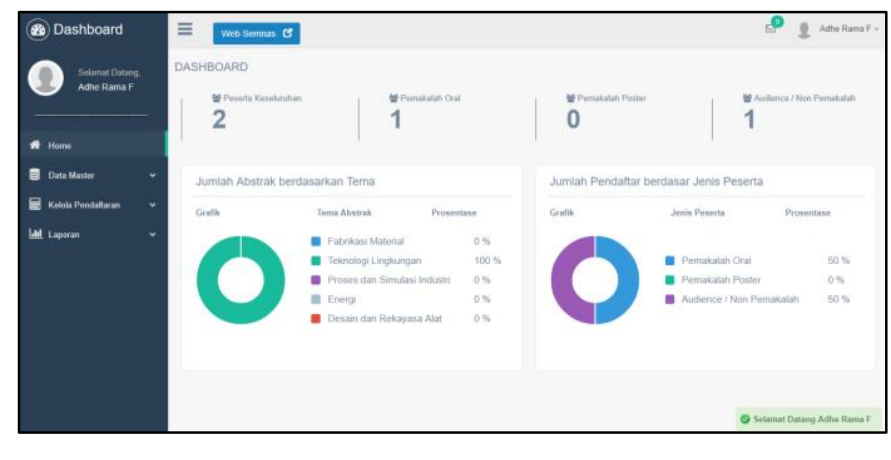

Gambar 11 Halaman Dashboard Admin

Untuk calon pemakalah atau peserta dapat melakukan login dengan email dan password yang dimasukkan ketika pemakalah atau peserta tersebut melakukan pendaftaran. Lebih jelasnya dapat dilihat pada Gambar 12. 


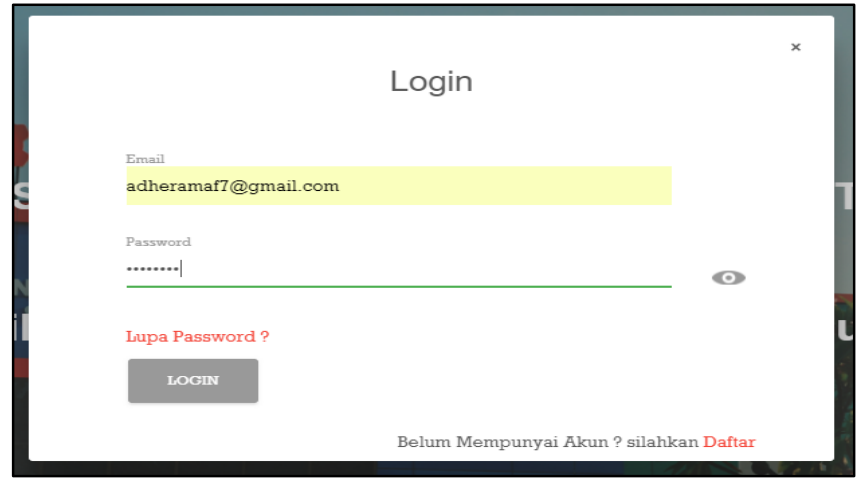

Gambar 12 Halaman Login Pemakalah

Apabila email dan atau password yang dimasukkan salah, sistem akan memuat ulang halaman dan memunculkan notifikasi di pojok kanan atas seperti pada Gambar 13

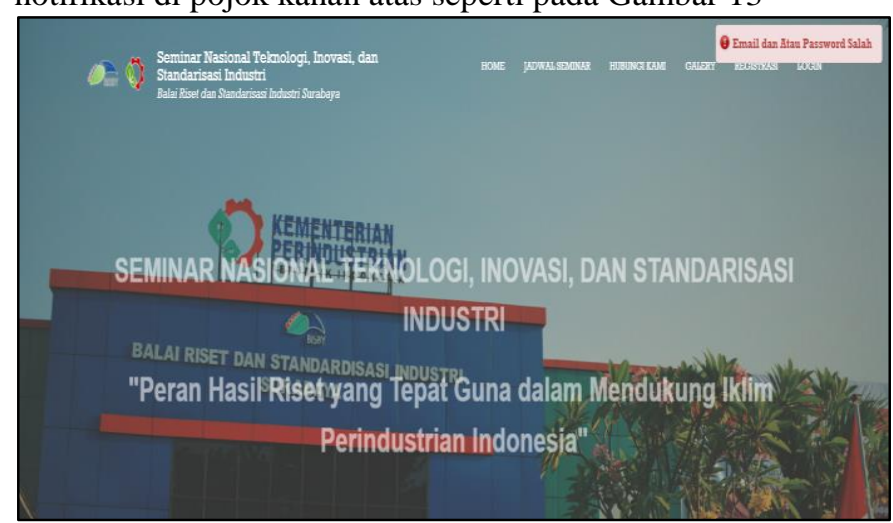

Gambar 13 Halaman Login Gagal

Ketika pemakalah atau peserta berhasil memasukkan email dan password yang sesuai maka sistem akan memuat ulang halaman dan memunculkan notifikasi "Selamat Datang". Sistem juga mengubah menu "Registrasi" dan "Login" menjadi "Akun" dan "Logout" seperti pada Gambar 14.

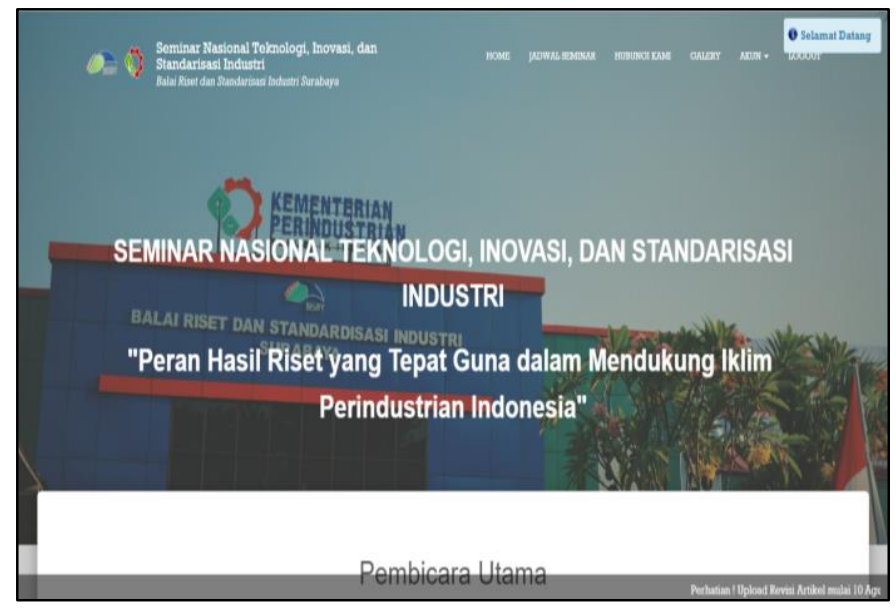

Gambar 14 Halaman Utama Pemakalah

\section{b) Halaman Master Admin}

Halaman master admin berfungsi untuk mengelola data admin. Halaman ini dapat diakses dengan membuka menu "Data Master" pada navigasi menu kiri. Halaman master admin menampilkan data admin secara keseluruhan seperti pada Gambar 15.

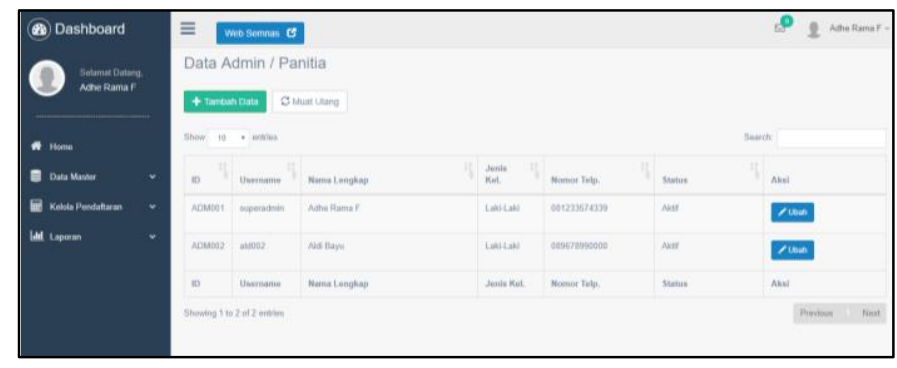

Gambar 15 Halaman Master Admin

Tombol "Tambah Data" dan "Ubah" digunakan untuk mengakses form master admin. Form master admin digunakan untuk menambahkan data admin dan mengubah data admin. Form master admin terdiri dari: nama lengkap, jenis kelamin, nomor telepon, dan status. Form admin dapat dilihat pada Gambar 16

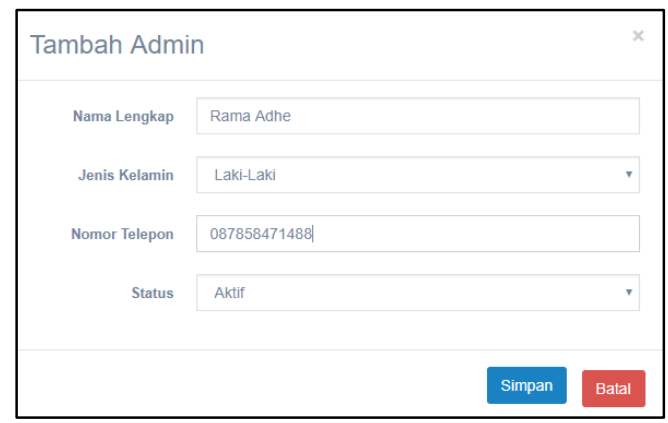

Gambar 16 Form Data Admin

\section{c) Halaman Master Jenis Peserta}

Halaman master jenis peserta berfungsi untuk mengelola data jenis peserta. Halaman ini dapat diakses dengan membuka menu "Data Master" pada navigasi menu kiri. Halaman master jenis peserta menampilkan data jenis peserta secara keseluruhan seperti pada Gambar 17.

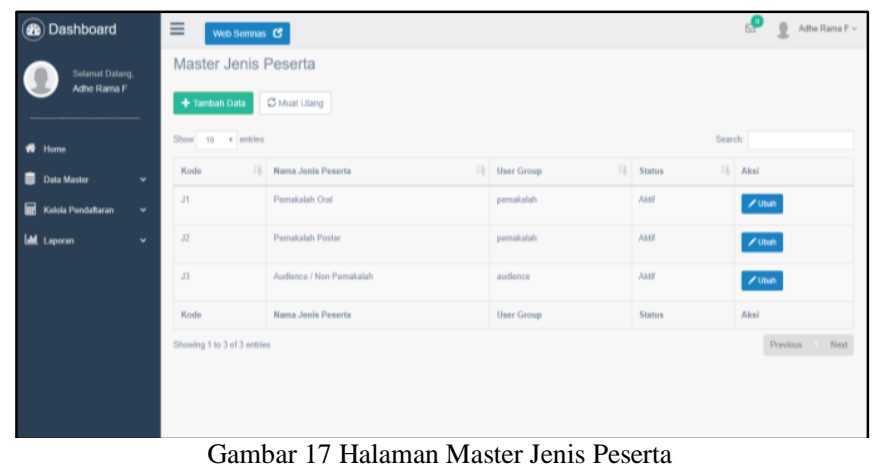


Tombol "Tambah Data" dan "Ubah" digunakan untuk mengakses form master jenis peserta. Form master jenis peserta digunakan untuk menambahkan data jenis peserta dan mengubah data jenis peserta. Form jenis peserta terdiri dari: nama jenis peserta, usergroup, dan status. Form jenis peserta dapat dilihat pada Gambar 18.

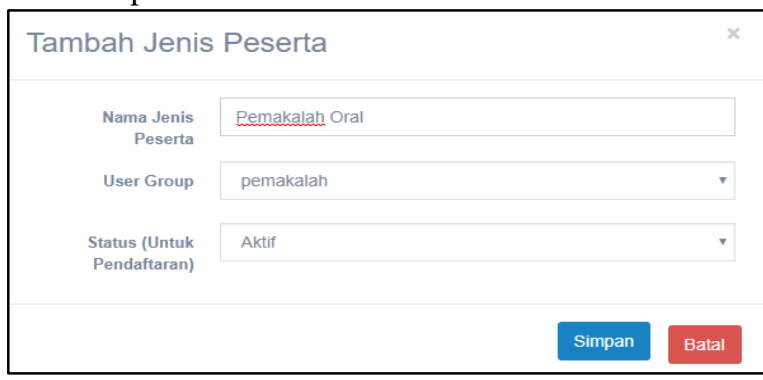

Gambar 18 Form Master Jenis Peserta

\section{d) Halaman Master Subjenis Peserta}

Halaman master subjenis peserta berfungsi untuk mengelola data subjenis peserta. Halaman ini dapat diakses dengan membuka menu "Data Master" pada navigasi menu kiri. Halaman master subjenis peserta menampilkan data subjenis peserta secara keseluruhan seperti pada Gambar 19.

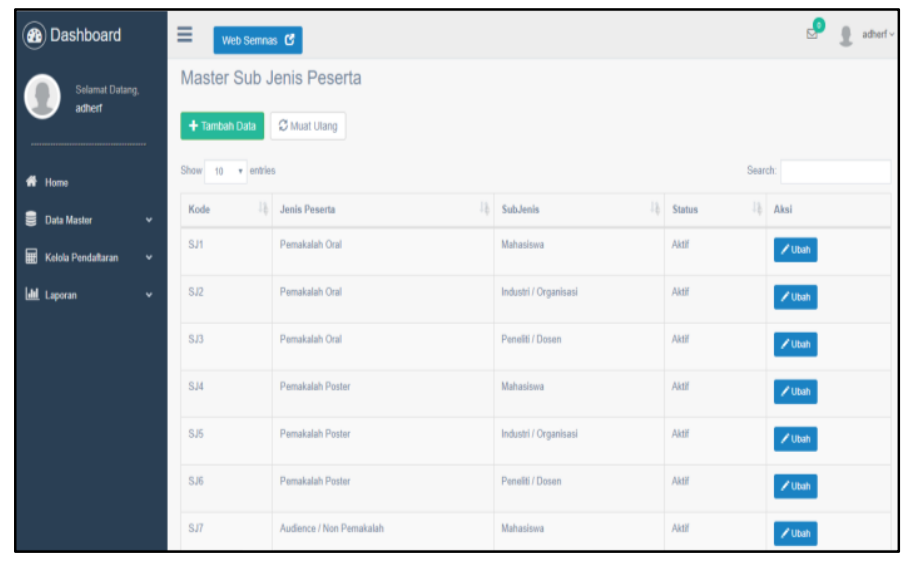

Gambar 19 Halaman Master Subjenis Peserta

Tombol "Tambah Data" dan "Ubah" digunakan untuk mengakses form master subjenis peserta. Form master subjenis peserta digunakan untuk menambahkan data subjenis peserta dan mengubah data subjenis peserta. Form subjenis peserta terdiri dari: jenis peserta, nama subjenis peserta, dan status. Form subjenis peserta dapat dilihat pada Gambar 20.

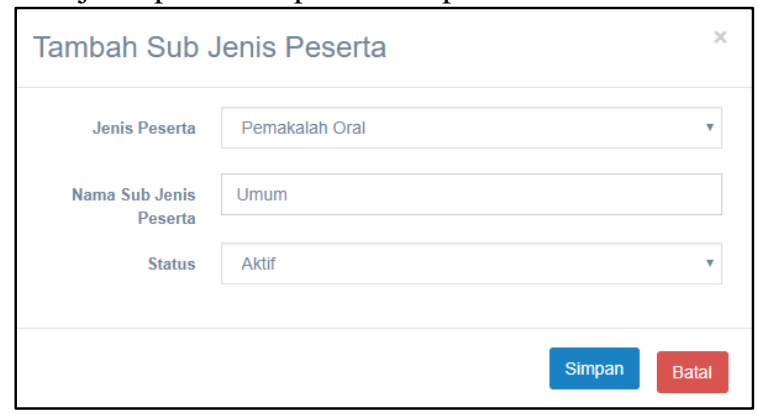

Gambar 20 Form Master Subjenis Peserta

\section{e) Halaman Master Tema}

Halaman master tema berfungsi untuk mengelola data tema. Halaman ini dapat diakses dengan membuka menu "Data Master" pada navigasi menu kiri. Halaman master tema menampilkan data tema artikel secara keseluruhan seperti pada Gambar 21. Untuk menambah data tema, pengguna dapat menekan tombol "Tambah Data".

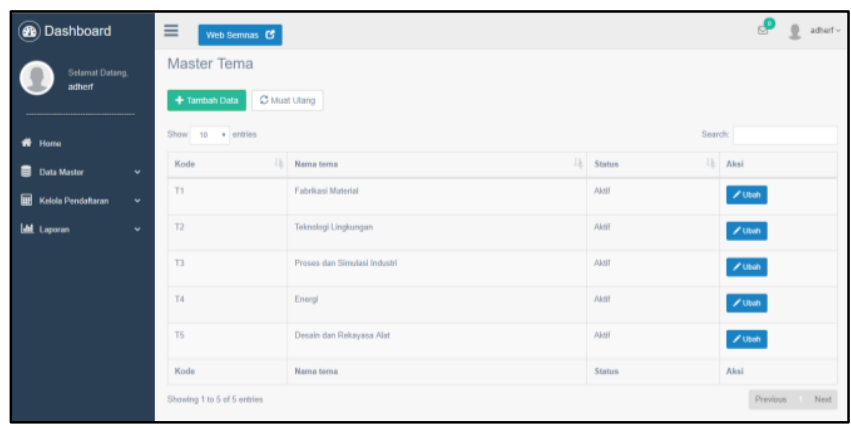

Gambar 21 Halaman Master Tema

Tombol "Tambah Data" dan "Ubah" digunakan untuk mengakses form master tema. Form master tema digunakan untuk menambahkan data tema dan mengubah data tema. Form data tema yang terdiri dari: nama tema dan status. Form tema dapat dilihat pada Gambar 22.

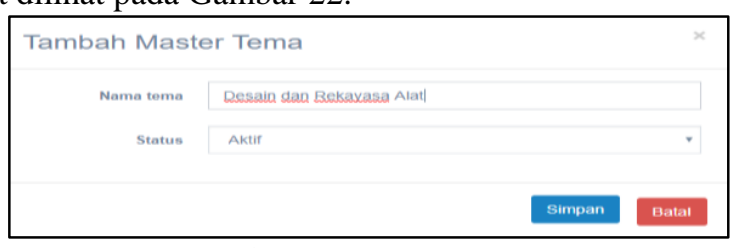

Gambar 22 Form Master Tema

\section{f) Halaman Manajemen Abstrak}

Halaman manajemen abstrak berfungsi untuk mengelola abstrak dari sisi pemakalah. Halaman ini dapat diakses dengan membuka menu "Akun" pada navigasi menu atas. Data abstrak yang telah di-upload oleh pemakalah akan ditampilkan di halaman manajemen abstrak. Halaman manajemen abstrak dapat dilihat pada Gambar 23.

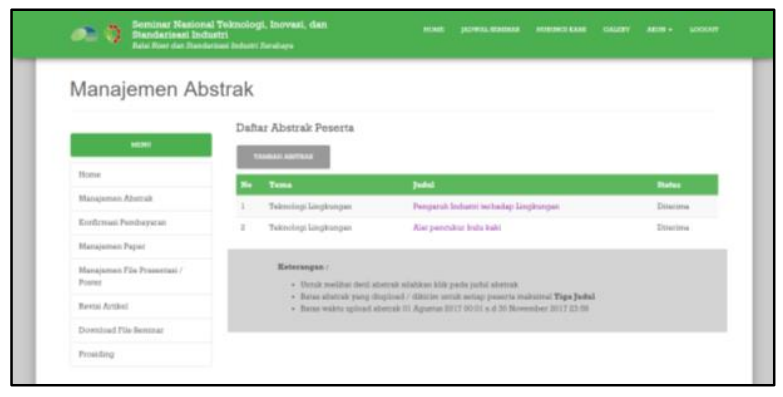

Gambar 23 Halaman Manajemen Abstrak Pemakalah

Tombol "Tambah Abstrak" berfungsi untuk mengakses halaman tambah abstrak. Pada halaman tambah abstrak terdiri dari beberapa isian yaitu : judul, tema, isi abstrak, nama penulis (maksimal 6), kata kunci, cakupan 
wilayah,bahasa, referensi, dan file softcopy abstrak. Tombol "Simpan" digunakan untuk menyimpan data abstrak ke database dan mengarahkan pengguna kembali ke halaman manajemen abstrak. Halaman tambah abstrak dapat dilihat pada Gambar 24.

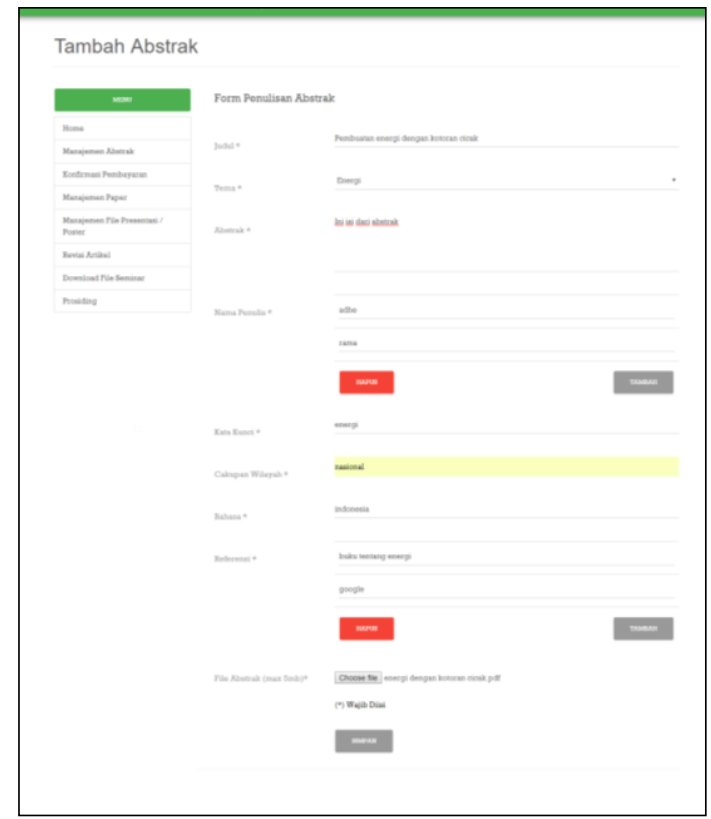

Gambar 24 Halaman Tambah Abstrak

\section{g) Halaman Seleksi Abstrak}

Halaman seleksi abstrak berfungsi untuk mengelola abstrak yang di-upload oleh pemakalah. Untuk mengakses halaman ini dengan membuka menu "Kelola Pendaftaran" pada menu navigasi kiri. Halaman seleksi abstrak menampilkan seluruh data abstrak yang di-upload pemakalah. Lebih jelasnya dapat dilihat pada Gambar 25.

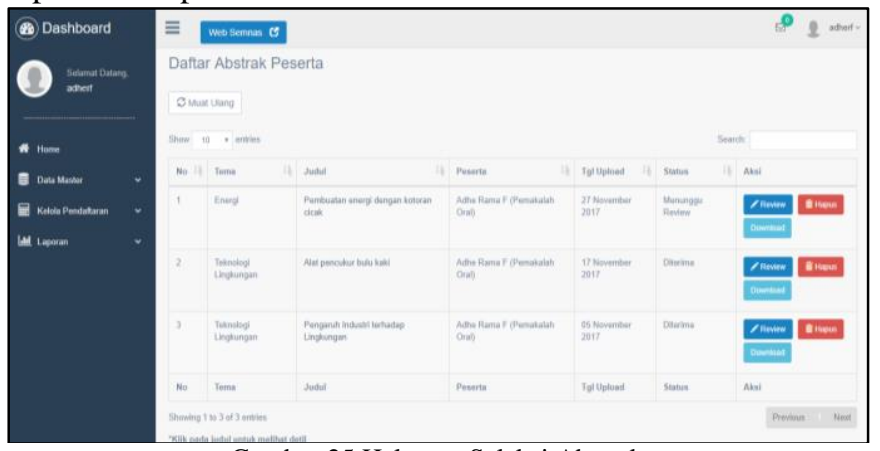

Gambar 25 Halaman Seleksi Abstrak

Tombol "Review" berfungsi untuk mengakses form review abstrak. Form review abstrak dapat dilihat pada Gambar 26. Pada form review abstrak ditampilkan tema dan judul abstrak yang dipilih untuk di-review.

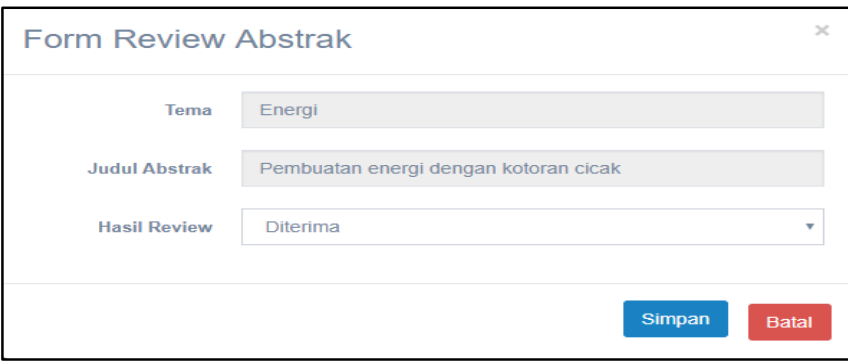

Gambar 26 Form Review Abstrak

\section{h) Halaman Manajemen Paper}

Halaman manajemen paper berfungsi untuk mengelola paper dari sisi pemakalah. Halaman ini dapat diakses dengan membuka menu "Akun" pada navigasi menu atas. Data paper yang telah di-upload oleh pemakalah akan ditampilkan di halaman manajemen paper. Link "Klik untuk Upload Paper" berfungsi untuk menampilkan form upload paper. Form upload paper terdiri dari: nama paper dan file softcopy paper. Halaman manajemen paper dapat dilihat pada Gambar 27.

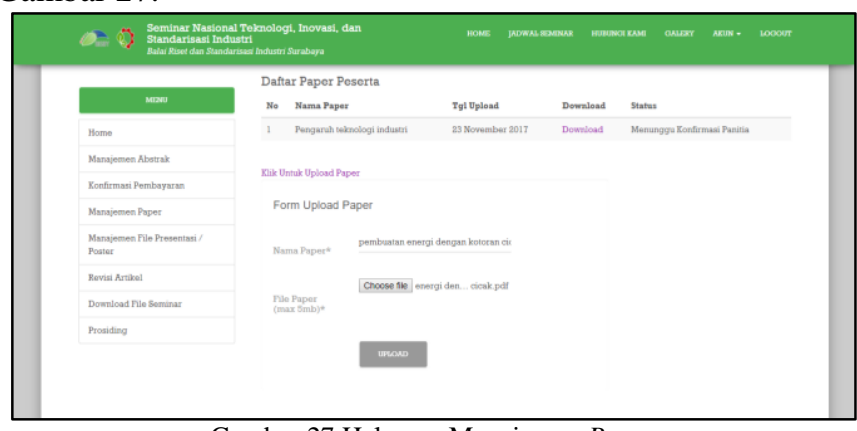

Gambar 27 Halaman Manajemen Paper

\section{i) Halaman Seleksi Paper}

Halaman seleksi paper berfungsi untuk mengelola paper yang di-upload oleh pemakalah. Untuk mengakses halaman ini dengan membuka menu "Kelola Pendaftaran" pada menu navigasi kiri. Halaman seleksi paper menampilkan seluruh data paper yang di-upload pemakalah. Lebih jelasnya dapat dilihat pada Gambar 28.

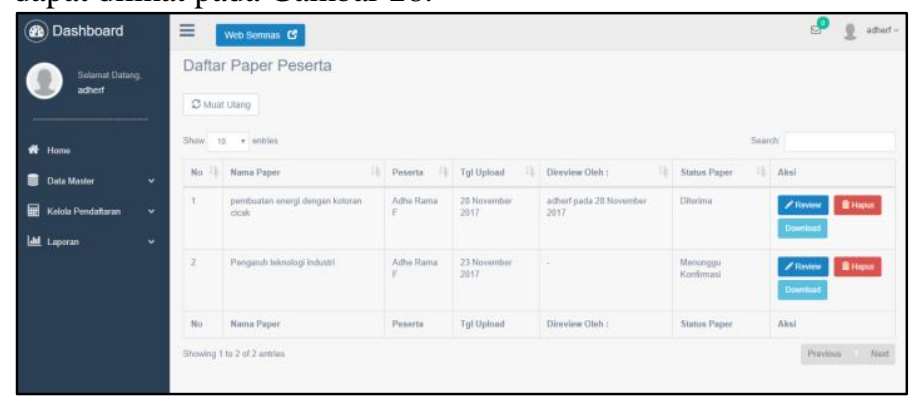

Gambar 28 Halaman Seleksi Paper

Tombol "Review" berfungsi untuk mengakses form review paper. Pada form review paper ditampilkan nama paper yang dipilih untuk di-review. Form review paper dapat dilihat pada Gambar 29. 


\section{Form Review papper}

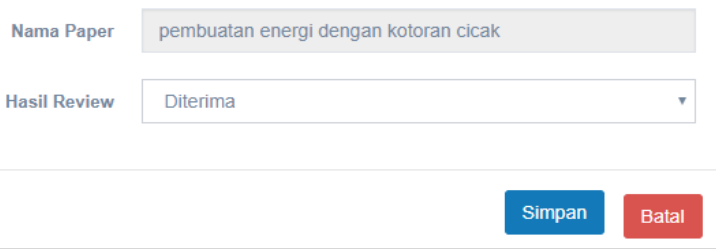

Gambar 29 Form Review Paper

\section{j) Halaman Cetak Laporan}

Halaman cetak laporan berfungsi untuk menampilkan data laporan sesuai dengan jenis laporan yang dipilih oleh pengguna. Untuk mengakses halaman laporan dengan membuka menu "Laporan" pada menu navigasi kiri. Kemudian memilih jenis laporan yang akan ditampilkan. Pada halaman laporan terdapat tombol cetak laporan. Lebih jelasnya dapat dilihat pada Gambar 30. Pada penjelesan kali ini menggunakan jenis laporan abstrak diterima.

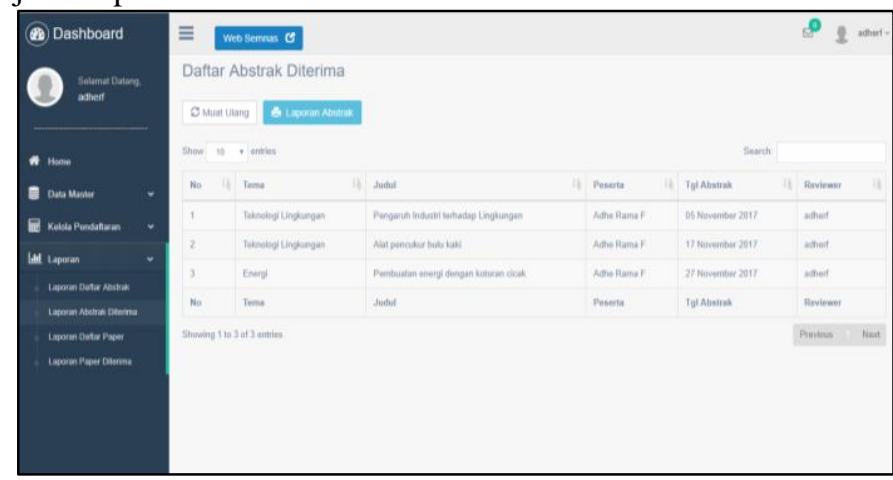

Gambar 30 Halaman Laporan

Tombol cetak laporan berfungsi untuk mengakses halaman cetak laporan yang di dalamnya terdapat preview dari laporan yang akan dicetak seperti pada Gambar 31. Pengguna dapat langsung mencetak laporan maupun menyimpan dalam bentuk PDF.

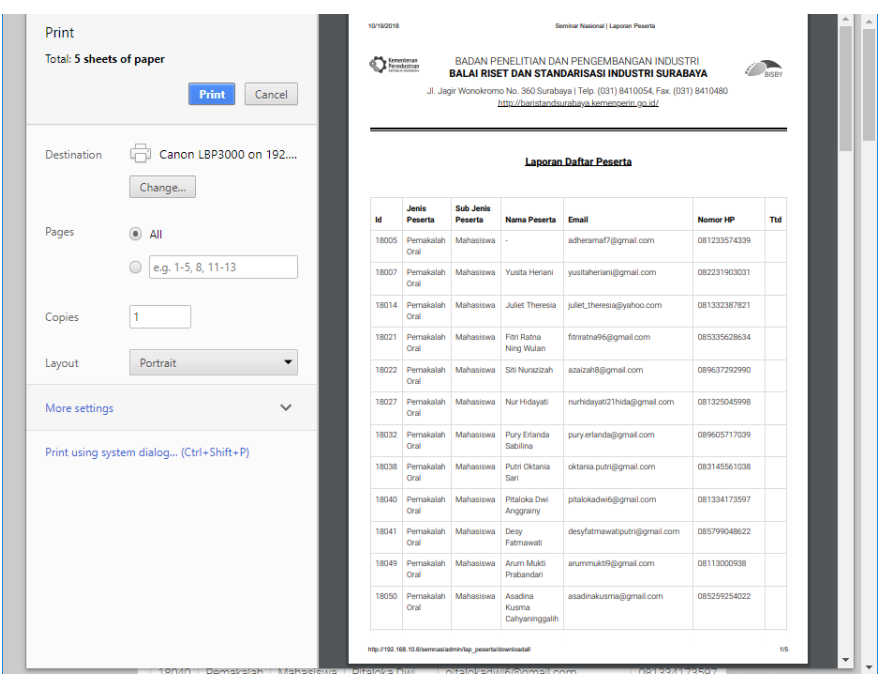

Gambar 31 Halaman Cetak Laporan

\section{KESIMPULAN}

\section{A. Kesimpulan}

Setelah melakukan analisa dan perancangan, serta implementasi Rancang Bangun Aplikasi Seleksi Abstrak dan Paper Seminar Nasional, maka dapat diperoleh kesimpulan sebagai berikut :

[1]. Aplikasi yang dibuat membantu hal pengiriman abstrak dan paper serta pencatatan hasil seleksi abstrak dan paper oleh panitia.

[2]. Aplikasi dalam sistem ini, menghasilkan laporan-laporan seperti laporan abstrak keseluruhan, abstrak diterima, paper keseluruhan, dan paper diterima yang dapat membantu sebagai alat pengambilan keputusan untuk kedepannya.

\section{UCAPAN TERIMA KASIH}

Baristand Industri Surabaya khusunya Seksi Teknologi Industri dan Seksi Pengembangan Jasa Teknis bagian Teknologi Informasi yang telah berperan aktif dalam penentuan spesifikasi sistem informasi, uji coba dan perbaikan sistem saat sistem telah beroperasi.

\section{DAFTAR PUSTAKA}

[1]. Halim Budi Santoso,Christopher Malvin,Rosa Delima, Pengembangan Sistem Informasi Pendataan Petani Dan Kelompok Tani, Seminar Nasional Sistem Informasi Indonesia (SESINDO), 2017

[2]. Fani Kristiani,Melkior Sitokdana,Agustinus Fritz Wijaya, Perancangan Dan Implementasi Sistem Informasi Manajemen Pencatatan Aset Berbasis Web (Studi Kasus: Kantor Perpustakaan Dan Arsip Daerah Kota Salatiga), Seminar Nasional Sistem Informasi Indonesia (Sesindo), 2017

[3]. Herlambang, Soendoro dan Haryanto Tanuwijaya. 2005. Sistem Informasi: Konsep, Teknologi \& Manajemen. Surabaya: Graha Ilmu.

[4]. Hidayatullah, Priyanto dan Jauhari Khairul Kawistara. 2014 Pemrograman Web Edisi Revisi. Bandung: Informatika.

[5]. Kadir, Abdul. 2002. Pemrograman WEB Mencakup: HTML, CSS JavaScript \& PHP. Yogyakarta: Andi.[6] Sutabri, Tata. 2003. Analisa Sistem Informasi. Yogyakarta: Andi.

[6]. Wahyudi, Bambang. 2007. Konsep Sistem Informasi dari Bit sampai ke Database. Yogyakarta: Andi.

[7]. Ratna, Saptono Arif, Nainggolan Jefri. 2017. PERANCANGAN SISTEM INFORMASI SELEKSI DAN PEREKRUTAN CALON KARYAWAN. Jurnal Maklumasika Vol 3 No. 2 Januari 2017 hal 150-159.

[8]. Wulan Ayu, Ilham Perdana. Desember 2014. Perancangan Sistem Informasi Rekruitmen dan Seleksi karyawan berbasis web di PT. QWORDS Company International. Jurnal Manajemen Indonesia. Vol 14 No. 3.

[9]. Boni Mariska Ratnawati, Analisis Seminar Lokal, Regional, Nasional dan Internasional .

[10]. https://easychair.org/conferences.cgi, diakses pada 17 Oktober 2018.

[11]. https://edas.info/doc/authors.html diakses pada 17 Oktober 2018. 